\title{
DETECTION OF CHANGES IN THE HYDROLOGICAL BALANCE IN SEVEN RIVER BASINS ALONG THE WESTERN CARPATHIANS IN SLOVAKIA
}

\author{
Anita, KESZELIOVÁ ${ }^{*}$, Kamila, HLAVČOVÁ ${ }^{1}$, Michaela, DANÁČOVÁ ${ }^{1}$, Zuzana, DANÁČOVÁ and Ján, SZOLGAY
}

\begin{abstract}
Due to a changing climate, likely changes to a hydrological regime are one of the primary sources of uncertainty to consider in managing water resources. In Slovakia, a decline in the country's water resources, combined with a change in the seasonality of runoff and an increase in the extremeness of floods and droughts, represents a potential threat. The objective of the paper was to explore trends in the components of the long-term hydrological balance of various river basins to detect the impacts of changing climate conditions along the Western Carpathians. The proposed method is a comparative exploratory analysis of the hydrological balance of the selected river basins. Temporal changes in the catchments' average air temperatures, precipitation, runoff, and their differences (considered as an index of the actual evapotranspiration), were estimated for 49 years of data; two non-overlapping sub-periods (25 and 24 years) in the seven river basins were also compared. This work also aims at evaluating the applicability of gridded inputs from the CarpatClim database for modelling the hydrological balance over an extended period. The results document the impact of the rising air temperature and, in part, local physiographic factors on the changes in runoff and actual catchment evapotranspiration.
\end{abstract}

\section{Address}

1 Department of Land and Water Resources Management, Slovak University of Technology in Bratislava, Bratislava, Slovakia

2 Slovak Hydrometeorological Institute, Bratislava, Slovakia

* Corresponding author: anita.keszeliova@stuba.sk

\section{Key words}

- Hydrological balance,

- Climate change,

- Evapotranspiration, Budyko-Tomlain,

- Detection of changes,

- Trend analysis,

- Western Carpathians.

\section{INTRODUCTION}

Global changes indirectly affect the timing and quantity of runoff and alter the hydrological regime in many parts of the world. Sustainable development, which has become an increasingly significant imperative for human society, is heavily dependent on the availability of water. However, the amount of available water resources is threatened by both climate change and human activities. Evapotranspiration, which includes all forms of evaporation and transpiration through plants, plays an important role in the water, energy, and carbon cycles. It directly controls forest management, agricultural productivity and the availability of water for society (Duethmann and Blöschl, 2018). Water scarcity can therefore be considered a severe problem for the future of humanity. In this respect, a quantitative evaluation of how, and on what spatial and temporal scales, such environmental changes may affect the temporal and spatial variability of actual catchment evapotranspiration and, indirectly, the capacity of water resources in Slovakia, deserves continuing attention.

Territorial evapotranspiration values cannot be directly measured, but we can assess them indirectly. Estimates can be based on at site experimental micrometeorological assessments, pan evaporimeters and lysimeters (Hobbins et al., 2004), spatial estimates by remote sensing (Zhang et al., 2010; Gao et al., 2010), and outputs from rainfall-runoff models (e.g., Parajka et al., 2004; Huang et al., 2020). In addition, we can use spatial interpolation methods from empirical point estimates of actual evapotranspiration made by a large number of methods of diverse 
complexities (Hobbins et al., 2001; Zhang et al., 2001; Lapin et al., 2016). They are also estimable by hydrological mapping (e.g., Parajka et al., 2004; Melo et al., 2013). Another robust and straightforward possibility of how to estimate actual (catchment) evaporation is a decadal evaluation of the hydrological balance equation (on a catchment scale) (e.g., Zhang et al., 2012), as changes in storage in catchments can usually be considered insignificant over decadal scales (Duethmann and Blöschl, 2018).

Due to the difficulty that the territorial values of actual evapotranspiration, especially on large spatial scales, cannot be directly measured, changes in the values and their drivers are still debated in the literature (Duethmann and Blöschl, 2018). However, many hydrologists have reported that actual evapotranspiration has regionally increased in many parts of the world in recent decades (Zhang et al., 2015).

Various studies have explored trends in actual evapotranspiration based on the water balance and have generally found increases in its values in recent decades (Domokos, Sass, 1990; Mills 2001; Weingartner et al., 2007; Trenberth et al., 2007). A global study found positive (but not always significant) trends in North and South America and Europe and negative trends in Africa and Siberia (Ukkola and Prentice, 2013). Many studies have been devoted to North America's river basins (Milly and Dunne, 2001; Walter et al., 2004; Gao et al., 2010; Kramer et al., 2015; Xiao et al., 2020). Countrywide assessments have been published, too (Mills, 2001; Weingartner et al., 2007; Duethmann and Blöschl, 2018; Mastrotheodoros et al., 2020; Xiao et al., 2020; TomasBurguera et al., 2021). Despite the difficulty of upscaling point estimates to catchment scales, the observed trends in catchments can also be complemented by point measurements (Keszeliova, 2020).

Long-term time series of monitoring the hydrological balance (including territorial evaporation) can enable the detection of changes in the processes involved and their comparisons. For example, several results of an evaluation of changes in hydrological cycle elements in Slovakia indicate that their regime has recently changed (e.g., Blaškovičová et al., 2019; Fendeková et al., 2018). Statistically significant but varying trends concerning their development have been found (e.g., Lapin et al., 2016; Pramuk et al., 2016; Ďurigová et al., 2019; Halmová et al., 2019; Ďurigová et al., 2020). Changes in snow cover as an component of the water balance in pristine mountain catchments were estimated by Holko et al. (2020). Vido et al. (2020) analyzed droughts in the Upper Hron region in Slovakia during the last 30 years.

This contribution aims to explore trends in the components of the long-term hydrological balance of the river basins in the Western Carpathians and detect changes attributable to changing climate conditions. We have used high-quality gridded data sets of precipitation and air temperatures from the CarpathClim project for the water balance and other climate variables as proxies. We have performed a comparative exploratory analysis of the hydrological balance of seven selected river basins. Temporal changes in the catchments' average air temperature, precipitation, runoff, and their differences (considered as an index of the actual evapotranspiration) have been estimated for 49 years of data and compared between two non-overlapping sub-periods (25 and 24 years). We have also aimed at evaluating the applicability of gridded inputs from the CarpatClim database to model the hydrological balance over an extended period.

\section{METHODOLOGY}

In catchment hydrology, we can evaluate possible longterm changes in runoff and changes in the actual territorial evapotranspiration with the hydrological balance equation (sometimes referred to as the "water budget"). The hydrological balance equation expresses the law of conservation of mass in a specific storage element (a water body) in the hydrological cycle. This mass balance is defined as relating the inputs and outputs of water and changes in its accumulation in a given water body within a fixed time interval (e.g., Makel' et al., 2002). Diverse forms of bordered water accumulation as an appropriate water body may be considered (i.e., lakes, river reaches, and groundwater reservoirs). However, the most common application is the estimation of a catchment's water balance. In practice, the time interval for the budget usually spreads from hours to several years.

The hydrological balance can be seen as the manifestation of a complex system of processes that operate on different spatial and temporal scales controlled by the relationship between the physiographic properties of basins and the climate (Jothityangkoon, Sivapalan, 2009). Besides the outflow, the specific output we are usually interested in is the actual evapotranspiration from a water body. In a catchment's hydrological balance, evapotranspiration (a volumetric element of the water budget) may be understood as the total amount of water evaporated from the catchment in all its forms over a specified period of time. Several synonyms for the term in diverse contexts, such as actual evapotranspiration, climatic evaporation, territorial evaporation, and total evaporation (Szolgay et al., 1997), can be used. The basis of territorial (total, climatic) evaporation from an entire catchment is the water storage in the basin, which primarily depends on the precipitation, runoff, and physiographic and hydrogeological conditions. The term "actual catchment evapotranspiration" will be used for the catchment scale herein in order to distinguish it from the actual evapotranspiration estimated at a certain point.

The relationship between the volumes of the elements of the hydrological cycle entering and leaving the area of a catchment during a given time interval $\Delta \mathrm{t}$ can be formally expressed by a simple equation, which can be written as follows (e.g., Keszeliová, 2020):

$$
Z+K+P_{P}+P_{R}+P_{P Z}=O_{P}+O_{P Z}+O_{O}+V+\Delta R
$$

where the individual symbols represent the following volumetric quantities:

Z - vertical precipitation,

$\mathrm{K}$ - horizontal precipitation (e.g., condensation of water vapour),

$\mathrm{P}_{\mathrm{P}}$ - the natural influx of water on a surface into a catchment,

$\mathrm{P}_{\mathrm{R}}$ - the anthropogenic transfer of water into a catchment,

$\mathrm{P}_{\mathrm{PZ}}$ - the natural groundwater inflow into a catchment,

$\mathrm{O}_{\mathrm{P}}$ - the natural surface outflow of water from the catchment,

$\mathrm{O}_{\mathrm{PZ}}$ - a natural underground outflow from a catchment,

$\mathrm{O}_{\mathrm{O}}$ - abstractions of the surface and groundwater transferred outside the catchment,

$\mathrm{V}$ - the total evaporation of water from the territory (actual catchment evapotranspiration), which includes all forms of water evaporation and plant transpiration),

$\Delta \mathrm{R}$ - change in the water storage in the catchment over the time interval $\Delta \mathrm{t}$ considered. 
The values of the variables of the balance equation can be expressed in volumetric units or units of depth for the given catchment (precipitation depth, runoff depth).

Two terms in the equation, i.e., $\mathrm{P}_{\mathrm{R}}$ and $\mathrm{O}_{\mathrm{O}}$, respectively, represent the results of anthropogenic activities. When investigating the hydrological balance of anthropologically undisturbed catchments, these values need to be specified. Otherwise, we must omit catchments in the analysis. The groundwater inflows and outflows, i.e., $\mathrm{P}_{\mathrm{PZ}}$ and $\mathrm{O}_{\mathrm{PZ}}$, respectively, need to be considered in cases when the hydrogeologic and orographic catchment boundaries differ or when the watercourse at the outlet of the catchment does not carry the whole amount of the outflow. The contribution of $\mathrm{P}_{\mathrm{PZ}}$ and $\mathrm{O}_{\mathrm{PZ}}$ to the balance sheet should be assessed on a case-by-case basis. When the catchment under scrutiny is large and the difference in the respective orographic and hydrogeological catchment areas is small, $\mathrm{P}_{\mathrm{PZ}}$ and $\mathrm{O}_{\mathrm{PZ}}$ do not have to be considered in the balance in practical applications (Parajka 1998; Parajka et al., 2004).

In an assessment of the hydrological balance over a more extended period (ranging from approx. five years up to decades (Duethmann and Blöschl, 2018)) or in areas with negligible catchment storage, we may simplify the equation by only taking into account only the precipitation, runoff, and actual catchment evapotranspiration. In such a case, however, we have to confirm that the total of these components over the period under assessment significantly exceeds any change in the water storage in the river basin during that period.

A simple equation can therefore express the evaluation of the water budget in these cases:

$$
Z=O+V
$$

where: Z, 0 , and $\mathrm{V}$ are the atmospheric precipitation, runoff, and actual catchment evapotranspiration, respectively, and $\Delta t$ is a relatively long period of time. The components of the hydrological balance are interlinked within the hydrological cycle, which allows for the indirect determination of the actual catchment evaporation from the precipitation and the river runoff (Parajka, 2001). By dividing both sides of the equation by the duration of the period under review $(\Delta t)$, we may express its terms as the long-term average values of the river basin's atmospheric precipitation, runoff, and actual evapotranspiration.

The outflow at a catchment's outlet can be considered the most reliably estimated term in the equation of the hydrological balance (assuming that all the water leaving the basin flows across the closing section of the river). Suppose a sufficiently dense rain gauge network is available in and around the catchment. In that case, the average areal precipitation can be interpolated by several standard approaches from point measurements (e.g., Valent and Výleta, 2015). Several regional and global gridded precipitation databases have recently been made available. However, their practical applicability and regional validity for estimating inputs into the hydrological balance need to be established on a case-bycase basis. This is especially needed when evaluating the temporal evolution of the hydrological balance in mountainous areas aimed at detecting changes in a catchment's output processes, especially the actual catchment evapotranspiration (Keszeliová, 2020).

Therefore, this study also aims at testing the usability of gridded rainfall data for modelling the hydrological balance over a more extended period in changing climate conditions. We have chosen the CarpatClim database from the available precipitation databases for our territory, because we can assume its representativeness for Slovakia, as it was created in cooperation between climatological communities of the countries in the Carpathian region (e.g., Szalai, Nejedlik, Štastný et al., 2012). Furthermore, by using it in the computation of the hydrological balance, we can also focus on detecting possible shortcomings in monitoring hydrological balances in long-term series caused by the particular density and positioning of the grid point network in relation to the position of our pilot basins. At the same time, we are also monitoring potential problems caused by sparse precipitation data in the mountains in the spatial interpolation of rainfall in a mountainous terrain in CarpathClim (Szentimrey and Bihary, 2007).

Finally, to verify the consistency of the actual catchment evapotranspiration against point estimates of the actual and potential evapotranspiration, we are also confronting the hydrological balance with the values of actual evapotranspiration calculated using the Budyko-Tomlain model in selected climate stations (Lapin et al., 2012). This model, which is generally well known and is considered a standard method in this region, is described in detail in Lapin et al. (2012). It is based on data on the air temperature and humidity, cloudiness, duration of sunshine, number of days with snow cover, and atmospheric precipitation. These elements are regularly measured at climate stations, i.e., the method is based on point measurements (Tomlain, 1997).

As the central part of this case study, we are addressing the question of how to use the hydrological balance equation to detect potential changes in the hydrological regime in annual time steps. We have analyzed the evolution of the hydrological balance and linear trends of its components in seven pilot basins, which are distributed along a transect arc from the southwest to the northeast across the Western Carpathians in Slovakia. Climatologically, the whole region is under the dominant influence of the North Atlantic Atmospheric Circulation. The mountainous character and geology of this region with its less developed groundwater storage favours the application of the simplified balance equation. We have assessed changes in the climate with linear trends in the time series of all three catchment-averaged components of the hydrological balance and the air temperature. We have tested the acceptance of the trends observed by the standard Mann-Kendall test (e.g., Durigová et al., 2019). We have used the hydrological year as the basis of the balance, as we consider it more appropriate for an annual balance. As opposed to a calendar year model, this concept attempts to ensure that precipitation falling in a year drains out of a watershed in the same year. The 49-year data covered by CarpathClim was thus shortened due to the delayed start of the hydrological year.

Consequently, 49 years of data and two non-overlapping subseries of 25 and 24 years, respectively, were analysed. Since we preferred comparing two the disjunctive periods in view of possible changes in the hydrological regime, this subdivision compromises the requirement of a sufficiently long period to determine trends in the hydrological balance. Furthermore, the second subseries falls within a period considered warmer than the first period (Durigová et al., 2019) and contains the year 2010, which featured very high precipitation.

\section{THE PILOT CATCHMENTS AND INPUT DATA}

We analyzed the evolution of the hydrological balance and the linear trends of its components in the seven pilot basins shown in 
Tab. 1 Basic morphological characteristics of the pilot catchments derived from a $20 \times 20 \mathrm{~m}$ DEM of Slovakia, the associated control climate stations, and their respective elevations

\begin{tabular}{|c|c|c|c|c|c|c|c|c|c|}
\hline \multirow{2}{*}{ Gauging station (ID) } & \multirow{2}{*}{ Catchment } & \multirow{2}{*}{$\begin{array}{c}\text { Basin } \\
\text { area }\end{array}$} & \multicolumn{3}{|c|}{ Catchment elevation } & \multirow{2}{*}{$\begin{array}{c}\text { Mean } \\
\text { catchment } \\
\text { slope }\end{array}$} & \multirow{2}{*}{$\begin{array}{l}\text { Catchment } \\
\text { orientation }\end{array}$} & \multirow{2}{*}{$\begin{array}{l}\text { Control climate } \\
\text { station }\end{array}$} & \multirow{2}{*}{$\begin{array}{l}\text { Climate } \\
\text { station } \\
\text { elevation }\end{array}$} \\
\hline & & & $\min$ & $\max$ & mean & & & & \\
\hline & & {$\left[\mathrm{km}^{2}\right]$} & [m a.s.1.] & [m a.s.1.] & [m a.s.1.] & [degrees] & $\begin{array}{c}\text { [Cardinal } \\
\text { directions] }\end{array}$ & & [m a.s.l.] \\
\hline Bohdanovce (5230) & Trnávka & 115.3 & 160.14 & 741.4 & 278.3 & 6.5 & S-E & Myjava & 349 \\
\hline Čachtice (6470) & Jablonka & 132.0 & 182.0 & 956.2 & 355.5 & 8.9 & S-E & Piešt’any & 165 \\
\hline Liešt’any (6620) & Nitrica & 136.6 & 335.1 & 1177.3 & 626.4 & 18.0 & $S$ & Prievidza & 260 \\
\hline Stráža (6150) & Varínka & 163.0 & 400.8 & 1676.9 & 774.8 & 20.0 & $\mathrm{~W}$ & Oravská Lesná & 780 \\
\hline Zubrohlava (5820) & Polhoranka & 139.0 & 606.7 & 1710.7 & 832.5 & 9.6 & S-E & Oravská Lesná & 780 \\
\hline Trstená 5840) & Oravica & 159.8 & 587.3 & 1654.6 & 871.5 & 11.6 & $\mathrm{~N}-\mathrm{W}$ & Oravská Lesná & 780 \\
\hline Lubochňa (5790) & L'ubochnianka & 118.3 & 440.7 & 1559.8 & 930.9 & 24.2 & $\mathrm{~N}$ & Liptovský Hrádok & 640 \\
\hline
\end{tabular}

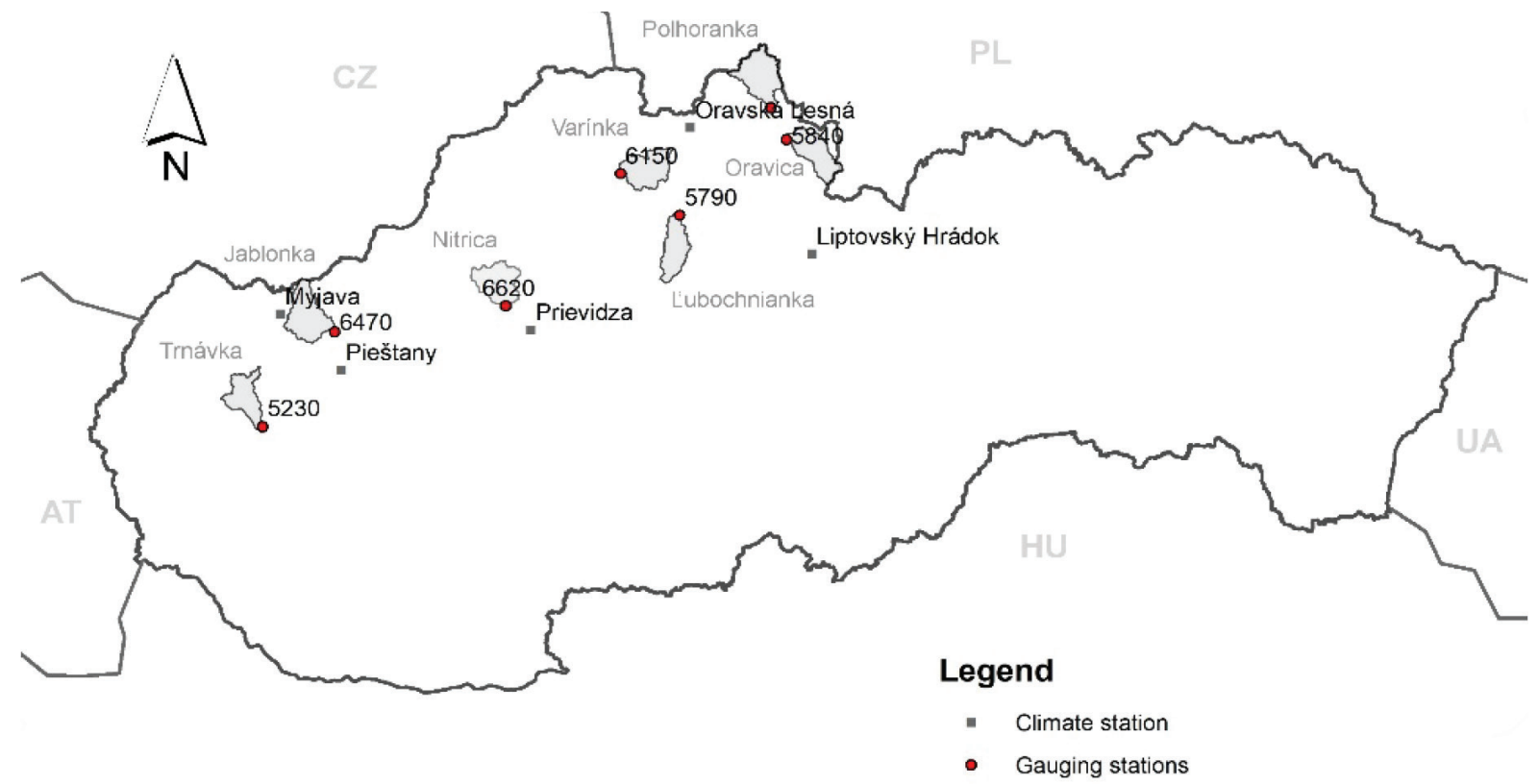

Fig. 1 The pilot catchments (shaded grey) and their identification numbers, the gauging stations (red dots), and the control climate stations (gray square) along the Western Carpathians in Slovakia

Fig. 1, which are distributed along a transect arc from the southwest to the northeast across the Western Carpathians in Slovakia. Tab. 1 shows the basic morphological characteristics of the pilot catchments. The catchment area was computed in a GIS from a $20 \times 20 \mathrm{~m}$ digital elevation model (DEM) of Slovakia. Mountainous catchments of a comparable (medium) size with an undisturbed hydrological regime were selected. With their altitudinal distribution and locations, they represent the diverse hydrological regimes of the pilot region, which are reflected in the physiographic characteristics and mean values of the measurable terms of the hydrological balance, as seen in Tab. 1 and Figs. 4, 6, and 7).

The database of the CarpatClim project (Szalai et al., 2012) was used for the meteorological inputs. The high resolution gridded database of the Carpathian Region offers 74 parameters of daily, monthly, and annual meteorological elements in calendar years. In the project's online database, the data are available in the network's grid points, as shown in Fig. 2. The outputs of the CarpatClim project are homogenized spatially representative time series of gridded climatological data, which were processed on a $0.1 \times 0.1$ degree grid, i.e., approx. $10 \times 10 \mathrm{~km}$. The area of Slovakia is covered by the grid points from 524 to 2240 . The MISH method (Meteorological Interpolation based on Surface Homogenised data, Szentimrey and Bihari, 2007) was used for spatial interpolation of the homogenised hydrometeorological time series from climate stations of the region on the grid points.

The monthly atmospheric precipitation totals and mean monthly air temperatures for the pilot basin areas in hydrological years were extracted from the CarpatClim database. We were limited by the temporal coverage of CarpatClim in the length of the data series, which was from 1962 to 2010. Therefore, we examined the whole range of 49 years and also, separately, two non-overlapping periods of 25 and 24 years, respectively. The Thiessen polygon method was chosen for calculating the average areal precipitation and air temperature over the catchments. The individual grid points of the CarpatClim database within the area of the catchments area or in their immediate surroundings were used as the centres of the polygons. Grid points from the Czech Republic and Poland have also been considered in the border regions. 


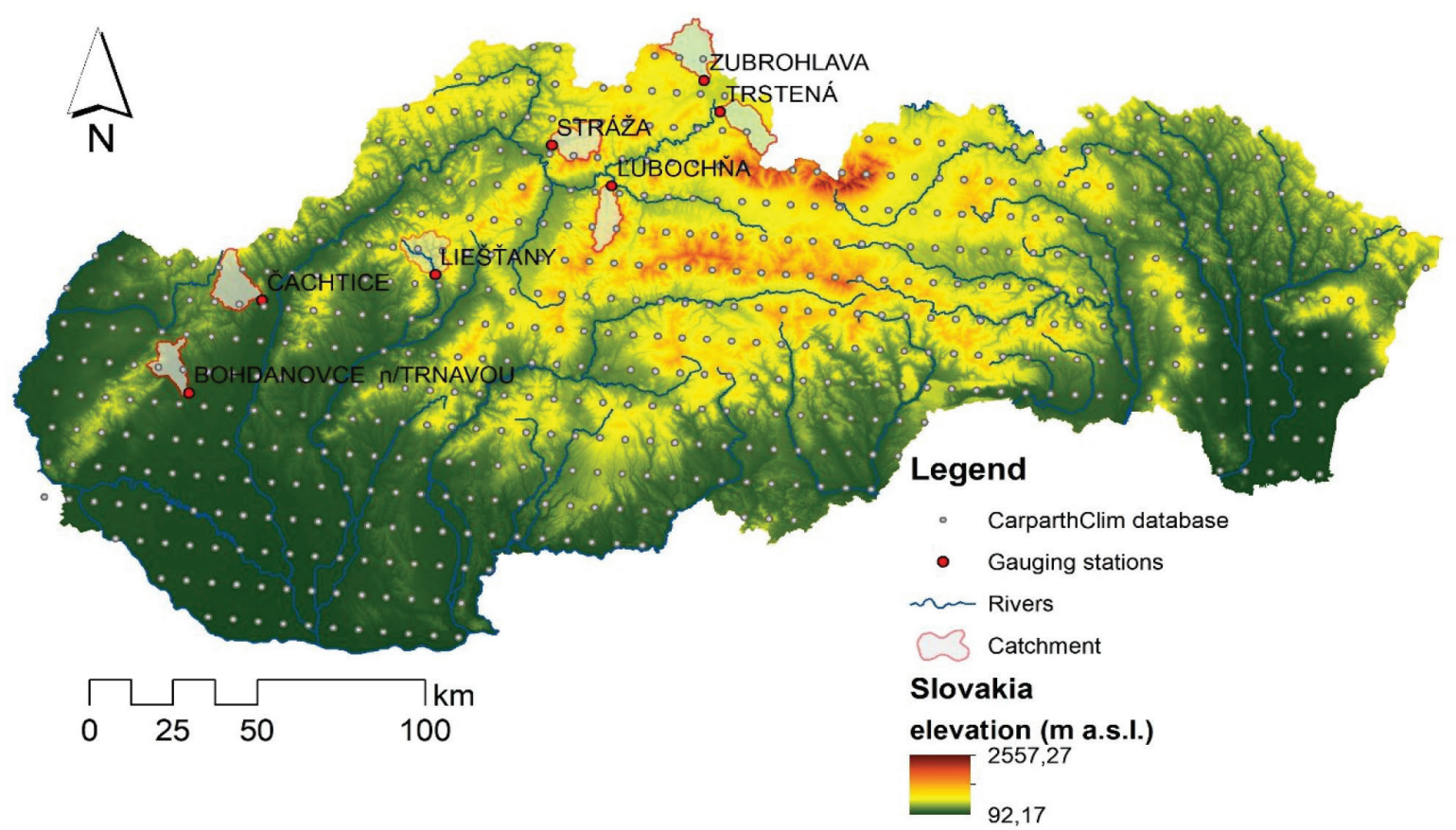

Fig. 2 The spatial distribution of the grid point network of the CarpatClim database and an illustration of the grid point coverage of the pilot catchments

The Slovak Hydrometeorological Institute (SHMÚ) provided river flow data from 1962 to 2010 for the closing sections in the selected catchments. The average annual flow rates $Q\left[\mathrm{~m}^{3} \mathrm{~s}^{-1}\right]$ were transformed into runoff depths in [mm] using the catchment areas assessed in a GIS from the $10 \times 10 \mathrm{~m}$ DEM of Slovakia.

The actual evapotranspiration in the climate stations nearest the pilot catchments that the SHMÚ maintains were estimated in a monthly time step from 1962 to 2010 by the Budyko-Tomlain method and made available by the Department of Meteorology and Climate Science at the Faculty of Mathematics, Physics and Informatics of Comenius University, Slovakia.

\section{RESULTS}

The linear trends in the time series of the annual values of the areal averages of all the component components of the hydrological balance were initially estimated in the pilot catchments. The air temperature, depth of precipitation, depth of runoff, and difference between precipitation and runoff (considered as an index of the actual catchment evapotranspiration) were examined. The time series of the potential and actual evapotranspiration estimates, made according to the Budyko-Tomlain method in the associated control climate stations, were also scrutinized. The analysis was carried out for the whole reporting period (1962-2010) and a control period (1962-2009), which did not contain the extremely wet year of 2010. Both sub-periods (1962-1986 and 1987-2010) were not considered due to the limited length of the series for any reliable trend analysis. The significance of the trends was assessed using the MannKendall test at the 95 and 90 percent levels of significance. Tab. 2 contains an evaluative summary of the trends and their significance for 1962-2010; Tab. 3 does the same for 1962-2009.

The increase in air temperature is statistically significant across the transect and reflects the effects of the warming climate in recent decades. An increase in the catchment precipitation is present in the trends but is not statistically significant at both

Tab. 2 Trends (positive - arrow up, negative - arrow down) and their statistical significance (YES or NO) at the $95 \%$ level from the MannKendall test in the series of the areal averages of the components of the hydrological balance (air temperature, precipitation, runoff, and precipitation - runoff) in the pilot catchments and in the series of potential (PET) and actual evapotranspiration (AE) estimates according to the Budyko-Tomlain method in the associated control climate stations in the period of 1962-2010

\begin{tabular}{|c|c|c|c|c|c|c|}
\hline \multirow{2}{*}{ Gauging station (ID) } & Air temperature & Precipitation & Runoff & $\begin{array}{l}\text { Precipitation - } \\
\text { Runoff }\end{array}$ & PET & $\mathrm{AE}$ \\
\hline & $1962-2010$ & $1962-2010$ & $1962-2010$ & $1962-2010$ & $1962-2010$ & $1962-2010$ \\
\hline Bohdanovce (5230) & $\uparrow \mathrm{YES}$ & $\uparrow \mathrm{NO}$ & $\downarrow$ YES & $\uparrow \mathrm{YES}$ & $\uparrow \mathrm{YES}$ & $\uparrow \mathrm{NO}$ \\
\hline Čachtice (6470) & $\uparrow \mathrm{YES}$ & $\uparrow \mathrm{NO}$ & $\downarrow \mathrm{NO}$ & $\uparrow \mathrm{NO}$ & $\uparrow \mathrm{YES}$ & $\uparrow \mathrm{NO}$ \\
\hline Liešt’any (6620) & $\uparrow \mathrm{YES}$ & $\uparrow \mathrm{NO}$ & $\downarrow \mathrm{NO}$ & $\uparrow \mathrm{NO}$ & $\uparrow \mathrm{YES}$ & $\uparrow \mathrm{NO}$ \\
\hline Stráža (6150) & $\uparrow \mathrm{YES}$ & $\uparrow \mathrm{NO}$ & $\downarrow \mathrm{NO}$ & $\uparrow \mathrm{NO}$ & $\uparrow \mathrm{YES}$ & $\uparrow \mathrm{YES}$ \\
\hline Zubrohlava (5820) & $\uparrow \mathrm{YES}$ & $\uparrow \mathrm{NO}$ & $\downarrow \mathrm{NO}$ & $\uparrow \mathrm{NO}$ & $\uparrow \mathrm{YES}$ & $\uparrow \mathrm{YES}$ \\
\hline Trstená 5840) & $\uparrow \mathrm{YES}$ & $\uparrow \mathrm{NO}$ & $\downarrow \mathrm{NO}$ & $\uparrow \mathrm{NO}$ & $\uparrow \mathrm{YES}$ & $\uparrow \mathrm{YES}$ \\
\hline Lubochňa (5790) & $\uparrow \mathrm{YES}$ & $\uparrow \mathrm{NO}$ & $\uparrow \mathrm{NO}$ & $\uparrow \mathrm{NO}$ & $\uparrow \mathrm{YES}$ & $\uparrow \mathrm{YES}$ \\
\hline
\end{tabular}


test levels. The runoff decreases in all the catchments except for the Lubochnianka River, which is a narrow valley with steep slopes and a northern orientation (for the shape of the catchment, see Fig. 5). The only statistically significant decrease in runoff occurred in the Trnávka River, which has the lowest elevation of the pilot catchments. Both Budyko-Tomlain proxy series confirm the trends in the actual catchment evapotranspiration. The higher rate of statistical significance can be attributed to the fact that this model considers a horizontal grass-covered surface at the climate stations with no runoff.

Tab. 3 Trends (positive - arrow up, negative - arrow down) and their statistical significance (YES or NO) at the $95 \%$ level from the MannKendall test in the series of the areal averages of the components of the hydrological balance (air temperatures, precipitation, runoff, precipitation-runoff) in the pilot catchments in the period $1962-2009$. Changes in the trends compared to 1962-2020 are marked yellow; changes in the significance are marked red

\begin{tabular}{|c|c|c|c|c|}
\hline \multirow{2}{*}{$\begin{array}{c}\text { Gauging } \\
\text { station }\end{array}$} & Temperature & Precipitation & Runoff & $\begin{array}{c}\text { Precipitation } \\
- \text { Runoff }\end{array}$ \\
\cline { 2 - 5 } & $1961-2009$ & $1961-2009$ & $1961-2009$ & $1961-2009$ \\
\hline Bohdanovce & $\uparrow$ YES & $\uparrow$ NO & $\downarrow$ YES & $\uparrow$ NO \\
\hline Čachtice & $\uparrow$ YES & $\uparrow$ NO & $\downarrow$ NO & $\uparrow$ NO \\
\hline Liešt’any & $\uparrow$ YES & $\uparrow$ NO & $\downarrow$ NO & $\uparrow$ NO \\
\hline Stráža & $\uparrow$ YES & $\downarrow N O$ & $\downarrow$ NO & $\uparrow$ NO \\
\hline Zubrohlava & $\uparrow$ YES & $\downarrow N O$ & $\downarrow$ NO & $\downarrow$ NO \\
\hline Trstená & $\uparrow$ YES & $\uparrow$ NO & $\downarrow$ YES & $\uparrow$ NO \\
\hline L'ubochňa & $\uparrow$ YES & $\uparrow N O$ & $\uparrow N O$ & $\uparrow N O$ \\
\hline
\end{tabular}

The precipitation in 2010 was extraordinarily high. Consequently, due to the high runoff coefficient in catchments at high elevations, the runoff and the actual catchment evapotranspiration were also affected. Furthermore, since 2010 was the last member in the series, it could influence the trends in those series. Therefore, the control series without considering this year was also evaluated; the results are in Tab. 3.

Changes in the precipitation trends occurred at higher elevations in the Varínka and Polhoranka catchments (mean catchment elevations of 774.8 and $832.5 \mathrm{~m}$ a.s.l., respectively), but neither are statistically significant. The runoff trends remained unchanged with the exception of that in the Oravica River, which became significant. The actual catchment evapotranspiration turned to insignificant in the Trnávka catchment, and the trend reversed without being significant in the Polhoranka catchment. Overall, the general tendencies observed for 1962-2010 were not really affected.

As the next step in the analysis, the long-term hydrological balance was assessed for the whole reporting period (1962-2010) and both sub-periods (1962-1986 and 1987-2010).

The general tendencies are shown in Fig. 3 as the differences between the long-term averages of the components of hydrological balance in the two sub-periods. As in the previous analysis, the Budyko-Tomlain values of the potential and actual evapotranspiration estimates were also compared. These serve as useful proxies for the changes observed. The relative rise in the air temperature increased according to the altitude; however, the absolute change in the catchments is comparatively small (between 0.8 to 0.9 degrees), because the spatial variability in the changes in the air temperature is rather conservative. The changes in precipitation are positive, but are unsystematically distributed and negligible (in absolute values, between 14 and $37 \mathrm{~mm}$ ).

Consequently, the actual catchment evapotranspiration increased everywhere. Runoff decreased, except at the Polhoranka and Lubochnianka Rivers, where it remained almost stable due to local factors. The catchments'shapes, aspects, and relative locations on the CarpathClim grid points act as such causes, together with the catchments' storage. For example in the Polhoranka River, which flows through a flysh zone with low permeability, rapid runoff generation and comparatively low storage do not favor an increase in evapotranspiration, despite a rising air temperature and precipitation. Despite such local anomalies, an overall rise of the actual catchment evapotranspiration can be identified, and the Budyko-Tomlain data also underpin these tendencies.

The altitudinal zonality of the components of the hydrological balance and their temporal changes were compared across the transect. These values are visualized in Fig. 4. The catchments are ranked according to their respective mean elevations. The runoff and actual catchment evapotranspiration are expressed as percentages of the average areal precipitation in the periods 19621986, 1987-2010 and 1962-2010, respectively. The runoff is coded blue, while the actual catchment evapotranspiration is coded pink.

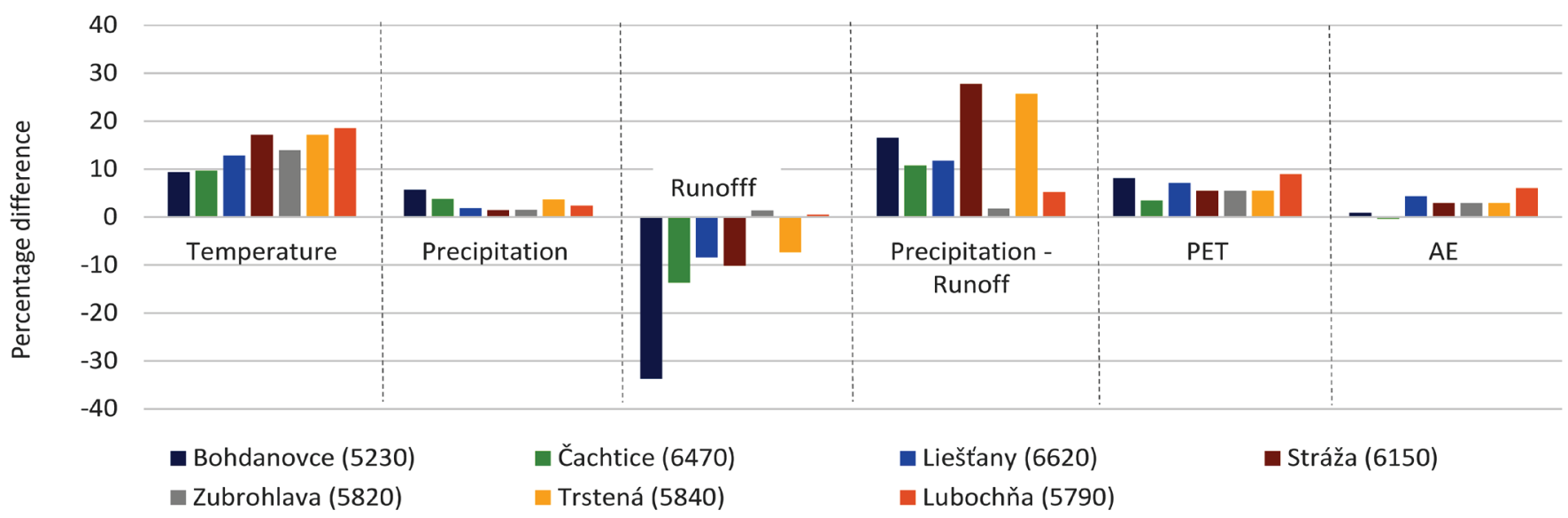

Fig. 3 Differences in the values of the long-term averages of the components of the hydrological balance and the potential and actual evapotranspiration estimates according to the Budyko-Tomlain method in the control climate stations between the two sub-periods of 1962 1986 and 1987-2010 in the catchments studied, which are ranked in ascending order of their mean elevation 


\begin{tabular}{|c|c|c|c|c|}
\hline $\begin{array}{c}\text { ID } \\
\text { Station } \\
- \\
\text { Catchment }\end{array}$ & $\begin{array}{c}\text { Mean } \\
\text { elevation }\end{array}$ & 1st period 1962-1986 & 2nd period 1987-2010 & Period 1962-2010 \\
\hline $\begin{array}{c}5230 \\
\text { Bohdanovce } \\
- \\
\text { Trnávka }\end{array}$ & $\begin{array}{c}278 \\
{[\mathrm{~m} \text { a.s.l. }]}\end{array}$ & & & . \\
\hline $\begin{array}{c}6470 \\
\text { Čachtice } \\
- \\
\text { Jablonka }\end{array}$ & $\begin{array}{c}355 \\
{[\mathrm{~m} \text { a.s.l.] }}\end{array}$ & & & \\
\hline $\begin{array}{c}6620 \\
\text { Liešt'any } \\
- \\
\text { Nitrica }\end{array}$ & $\begin{array}{c}626 \\
{[\mathrm{~m} \text { a.s.l. }]}\end{array}$ & & & \\
\hline $\begin{array}{c}6150 \\
\text { Stráža } \\
\text { - } \\
\text { Varínka }\end{array}$ & $\begin{array}{c}775 \\
\text { [m a.s.l.] }\end{array}$ & & & \\
\hline $\begin{array}{c}5820 \\
\text { Zubrohlava } \\
- \\
\text { Polhoranka }\end{array}$ & $\begin{array}{c}833 \\
{[\mathrm{~m} \text { a.s.l.] }}\end{array}$ & & & \\
\hline $\begin{array}{c}5840 \\
\text { Trstená } \\
\text { - } \\
\text { Oravica }\end{array}$ & $\begin{array}{c}872 \\
{[\mathrm{~m} \text { a.s.l.] }}\end{array}$ & & & \\
\hline $\begin{array}{c}5790 \\
\text { L'ubochňa } \\
- \\
\text { L'ubochnianka }\end{array}$ & $\begin{array}{c}931 \\
{[\mathrm{~m} \text { a.s.l.] }}\end{array}$ & & & \\
\hline
\end{tabular}

Fig. 4 Runoff and actual catchment evapotranspiration expressed as percentages of the average areal precipitation in all the pilot catchments ranked in ascending order of their mean elevations in the periods 1962-1986, 1987-2010, and 1962-2010 

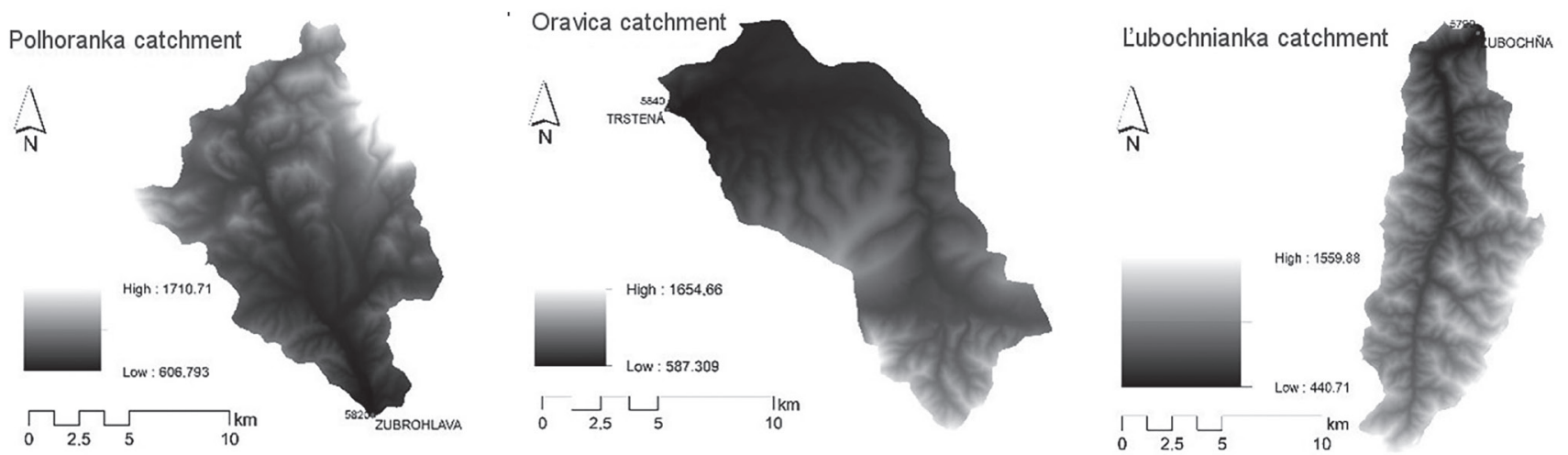

Fig. 5 River network, catchment shapes and orientation of the catchments at the highest elevations

The trends in the time series (Tables 2 and 3) manifest themselves accordingly in the changes in the hydrological balance. A comparison of values in the first and second periods (third and fourth columns) clearly shows the hydrological balance changes due to the rising air temperature. In general, the actual catchment evapotranspiration increased in the whole transect in the second period, although two catchments (Polohoranka and Lubochnianka Rivers) show only very moderate changes. These are rooted in the factors explained above.

The hydrological balance in the whole period exhibits values positioned between those of the two sub-periods. The altitudinal zonality present in both sub-periods is naturally maintained. The actual evapotranspiration decreases with altitude, and the runoff increases below $850 \mathrm{~m}$ a.s.1. The two catchments at the highest elevations do not quite follow this pattern, and they may even seem to slightly reverse it. Fig. 5 compares the catchment shapes, river networks and catchment orientations of the Polhoranka, Oravica and the Lubochnianka Rivers. These catchments are forested with a more developed storage capacity than the Polhoranka River, where the geology is dominated by less permeable flysh. Their catchment storage is also fed by a longer-lasting snow cover. These factors may enhance water availability for the evapotranspiration compared to the Polhoranka River at a similar elevation in the flysh zone.

\section{DISCUSSION}

Since the hydrological balance is controlled by climate and physiographic catchment properties, we decided to attempt to attribute the described patterns of change and behavior to causative factors in the discussion as the next step of the analysis. The variables in the equation of the long-term hydrological balance contain uncertainties. The (uncertain) rating curve influences the runoff estimates from the direct measurement of the water levels. Land use changes can influence a runoff regime over the long term. Also the catchment's average precipitation cannot be directly measured, and precipitation measurements contain systematic and random errors. Consequently, uncertainties in the actual catchment evapotranspiration occur.

Let us consider the outflow as the most reliable component of the balance. It is then necessary to indirectly verify the consistency of a catchment's average precipitation data, which can be affected by the quality of station data, the reliability of their interpolation into the gridded data of the CarpatClim database, and the distribution of the grids over our river basins. The Thiessen polygon method represents an additional source of uncertainty. Given these uncertainties, we used actual evapotranspiration data estimated from 18 climate stations in northwest Slovakia in

Tab 4. Comparison of the CORINE land use categories in the catchments at high elevations in 1990 and 2012

\begin{tabular}{|c|c|c|c|c|c|c|c|c|c|c|c|}
\hline $\begin{array}{c}\text { Gauging } \\
\text { station }\end{array}$ & Year & $\begin{array}{c}\text { Urban } \\
\text { area } \\
{\left[\mathrm{km}^{2}\right]}\end{array}$ & $\begin{array}{c}\text { Agric. } \\
\text { land } \\
{\left[\mathrm{km}^{2}\right]}\end{array}$ & $\begin{array}{c}\text { Pastures } \\
{\left[\mathrm{km}^{2}\right]}\end{array}$ & $\begin{array}{c}\text { Decid. } \\
\text { forest } \\
{\left[\mathrm{km}^{2}\right]}\end{array}$ & $\begin{array}{c}\text { Conif. } \\
\text { forest } \\
{\left[\mathrm{km}^{2}\right]}\end{array}$ & $\begin{array}{c}\text { Mixed } \\
\text { Forest } \\
{\left[\mathrm{km}^{2}\right]}\end{array}$ & $\begin{array}{c}\text { Tran. } \\
\text { wood- } \\
\text { land-shrub } \\
{\left[\mathrm{km}^{2}\right]}\end{array}$ & $\begin{array}{c}\text { Grass land } \\
{\left[\mathrm{km}^{2}\right]}\end{array}$ & $\begin{array}{c}\text { Water } \\
\text { areas } \\
{\left[\mathrm{km}^{2}\right]}\end{array}$ & $\begin{array}{c}\text { Bare } \\
\text { ground } \\
{\left[\mathrm{km}^{2}\right]}\end{array}$ \\
\hline \multirow{2}{*}{ Bohdanovce } & 1990 & 6.57 & 56.93 & 2.52 & 43.72 & 0.34 & 2.89 & 1.13 & - & 0.60 & 0.65 \\
& 2012 & 6.73 & 56.70 & 1.93 & 44.58 & 0.36 & 3.30 & 0.48 & - & 0.60 & 0.64 \\
\hline \multirow{2}{*}{ Čachtice } & 1990 & 11.12 & 93.24 & 0.59 & 30.43 & 3.26 & 19.71 & 4.57 & 0.06 & - & 0.03 \\
& 2012 & 11.3 & $\downarrow 90.59$ & 0.60 & $\uparrow 34.96$ & 3.93 & 18.24 & - & 0.06 & - \\
\hline \multirow{2}{*}{ Liešt’any } & 1990 & 1.70 & 24.77 & 13.33 & 62.23 & 2.35 & 25.40 & 6.72 & 0.07 & - & - \\
& 2012 & 2.39 & $\downarrow 19.89$ & $\downarrow 11.17$ & $\downarrow 51.85$ & 2.32 & $\uparrow 41.52$ & $\downarrow 7.43$ & - & - & - \\
\hline \multirow{2}{*}{ Stráža } & 1990 & 3.12 & 32.00 & 15.64 & 37.47 & 16.89 & 25.96 & 2.2 & 5.5 & - & 0.88 \\
& 2012 & $\uparrow 4.02$ & $\downarrow 28.27$ & $\downarrow 11.41$ & $\uparrow 40.73$ & 17.81 & $\uparrow 29.80$ & 2.00 & 4.60 & - & 0.41 \\
\hline \multirow{2}{*}{ Zubrohlava } & 1990 & 5.96 & 42.48 & 20.49 & 0.00 & 68.07 & 3.73 & 18.1 & 1.21 & - & - \\
& 2012 & 6.32 & $\uparrow 44.77$ & $\downarrow 14.41$ & $\uparrow 8.96$ & $\downarrow 66.00$ & $\uparrow 4.84$ & - & 1.71 & - & 12.94 \\
\hline \multirow{2}{*}{ Trstená } & 1990 & 5.20 & 26.46 & 26.9 & - & 66.65 & 1.75 & 4.75 & 0.37 & - & - \\
& 2012 & $\uparrow 6.26$ & $\uparrow 28.28$ & $\downarrow 20.59$ & - & 66.81 & $\uparrow 3.77$ & 5.50 & - \\
\hline \multirow{2}{*}{ Lubochňa } & 1990 & 0.66 & 2.21 & 0.66 & 20.81 & 40.61 & 47.26 & 1.28 & 4.79 & - & - \\
& 2012 & 0.77 & $\downarrow 1.79$ & 0.45 & 20.32 & $\downarrow 29.91$ & $\uparrow 51.34$ & - & 3.99 & - & 9.70 \\
\hline
\end{tabular}




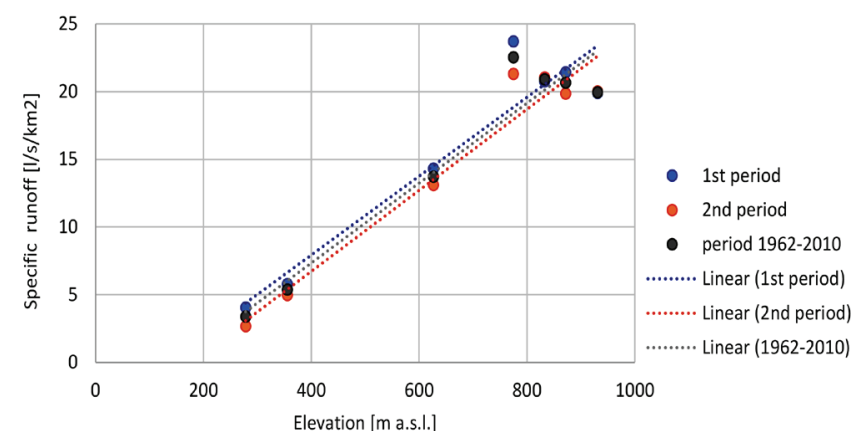

Fig. 6 Relationship between the long-term mean specific runoff and the mean catchment elevation in the pilot catchments

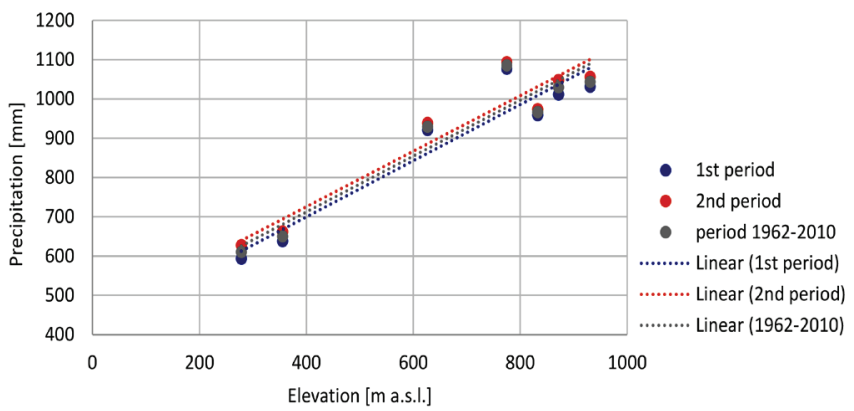

Fig. 7 Relationship between the long-term mean catchment average precipitation and the mean catchment elevation in the pilot

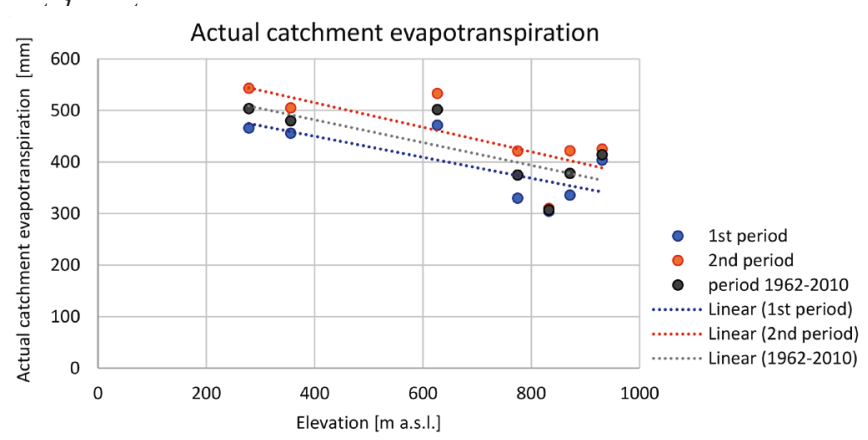

Fig. 8 Relationship between the long-term mean actual evapotranspiration estimated according to the Budyko-Tomlain method in the 18 selected climate stations and their elevation in northwest Slovakia

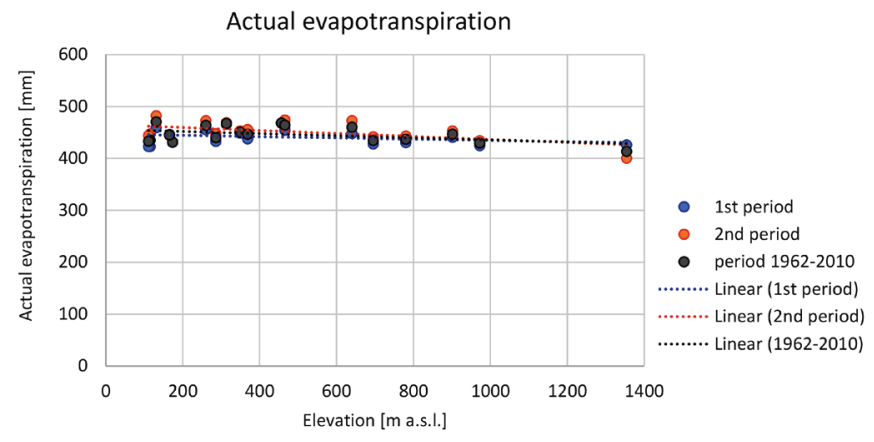

Fig. 9 Relationship between the long-term mean actual evapotranspiration estimated according to the Budyko-Tomlain method in the 18 selected climate stations and their elevation in northwest Slovakia

support of the results and conclusion as proxies. In addition, the potential influence of any land use changes was also assessed by a comparison of the CORINE land use categories in the catchments at high elevations in 1990 and 2012 (Tab. 4).
Overall, no dramatic land use changes have occurred. There is a slight increase in the amount of urban surfaces. Some transfers among the categories representing greened surfaces have taken place. In the Lubochnianka catchment, the area covered by coniferous forest decreased (probably due to bark beetle epidemics). Due to the characteristic brown color of the dead tree zones, these were probably incorrectly identified as bare ground. After clearcutting, these zones are usually quickly replaced by green shrubs. Therefore, the influence on the changes in the actual catchment evapotranspiration should not be seen as intense due to the mutual compensation of the green land use categories.

It can be seen that both the runoff and actual evapotranspiration in the two sub-periods are consistent in their magnitude in all the catchments and also follow the general regional pattern. The growing intensity of runoff generation (Fig. 6) in all three periods is a function of the catchment elevations. A similar, but complementary, tendency is seen in Fig. 8 with respect to the actual catchment evapotranspiration. Higher elevations in the Northern Carpathians relate to less intensive agricultural land use, higher forest coverage, and slopes. The orientation, catchment shape, and hydrogeology are further differentiating factors in the runoff generation, especially at higher elevations (above $800 \mathrm{~m}$ a.s.1.). Except for the Polhoranka catchment, the other catchments exhibit diverse geology indicating contrasting local storage capacities. While the Polhoranka and Oravica Rivers fit into the general tendency, the potential inconsistencies in the CarpathClim data combined with the effects of local factors may drive the spread of the points of the Lubochnianka and Varinka Rivers below and over the regression lines, respectively. For the actual catchment evapotranspiration (Fig. 8), the lower water resources, quick runoff and less precipitation (Fig. 7) in the Polhoranka catchment set the values lower. The relatively high specific runoff in the Varínka catchment is also fed by a higher rate of precipitation (Fig. 7). Consequently, the evapotranspiration is slightly below the average tendency in the transect. The relatively high evapotranspiration values of the Nitrica catchment can be attributed to the higher than average precipitation and its orientation towards the south, which implies higher energy available for evapotranspiration.

The evapotranspiration estimated according to the BudykoTomlain method (due to the boundary conditions considered by the model) better reflects the influence of air temperatures and precipitation than of other factors. Therefore, in Fig. 9, the relationship between the actual evapotranspiration estimated by this method was plotted against their elevations in the 18 selected control climate stations in all of northwest Slovakia. Since the changes in precipitation are minor, the decreasing tendency points toward the air temperature as the cause of any changes. These results support the assumption that the main driver of the decrease in actual catchment evapotranspiration with increasing catchment elevation is the rise in air temperature with the elevation.

Overall, these results are supported by findings in Fendeková et al. (2018), Blaškovičová et al. (2019), Garaj et al. (2019) and Durigová et al. (2020). The anomalies discussed above could not have been explained with the resources available for this study. Since the land use has not shown considerable changes, they may be attributed to the combined effects of the catchments' shapes, aspects, geology, local storage distribution, and the locations, density, and uncertainties in the interpolation of the CarpathClim grid points. These aspects will have to be targeted in future studies; until then we recommend careful data checks when CarpathClim 
data need to be used in catchments with higher elevations, especially for rainfall-runoff modelling with short time steps.

\section{CONCLUSIONS}

A changing climate, changes in a hydrological regime, and a decline in water resources represent potential severe threats to water management. Here, we studied the trends and changes in the components of the long-term hydrological balance to detect regime changes along a transect across the Western Carpathians. This work also aimed at evaluating the applicability of gridded inputs from the CarpatClim database for modelling the hydrological balance over an extended period for detecting changes. We detected inconsistencies, which could be possibly attributed to the sub-optimal location of the grid points of temperature and precipitation relative to our river basins. The influence of the increased uncertainty of interpolation of precipitation data in higher elevations has not been excluded, too.

This contribution also targeted possible discrepancies in the estimation of actual catchment evapotranspiration in the mountainous regions of the transect. We used a comparative exploratory analysis of the hydrological balance of the seven selected river basins. Temporal changes in the catchments' average air temperature, precipitation, runoff, and the differences in the last two (considered here as an index of the actual evapotranspiration) were estimated for 49 years of data and compared between two non-overlapping sub-periods ( 25 and 24 years). The unreliability of the identification of trends from a shorter period was also considered.

Given that both inputs into the equation of the long-term hydrological balance contain uncertainties, we also used proxy evapotranspiration data modelled according to the BudykoTomlain method. Inputs from 18 climate stations in northwest Slovakia were studied to support the results and conclusions.

Changes in land use were evaluated from the CORINE project and found to be only marginal between 1990 and 2012. This allowed us to consider the impact of the rising air temperature and, in part, the local physiographic factors, on the changes in runoff and actual catchment evapotranspiration as the main drivers of the documented changes in the hydrological balance.

In particular, the increase in air temperature was found to be statistically significant across the transect. An increase in the catchment precipitation was present in the trends but was not statistically significant at two levels of significance. Runoff generally decreased (with one exception), but only one significant change occurred in the Trnávka River, which is the one with the lowest elevation. The Budyko-Tomlain actual evapotranspiration proxy series confirmed the tendencies in the actual catchment evapotranspiration with significant trends.

The main conclusion related to water resources management is that the hydrological balance has changed towards an increase in actual catchment evapotranspiration and a decrease in runoff. However, local factors of runoff generation, especially catchment storage, can exhibit an influence at higher elevations (approx. above $800 \mathrm{~m}$ a.s.1.), thereby partially disguising the expected general tendencies at a given altitude. These factors can both lessen or intensify the changes in runoff and actual catchment evapotranspiration in catchments at similar altitudes. On the other hand, in lower elevations where runoff generation is less intensive, the influence of the climatic factors is decisive.
The applicability and usefulness of the gridded data from the CarpathClim database were demonstrated; however, further checks are still needed to confirm the general applicability for all of Slovakia, especially in mountainous catchments at higher elevations. One option is to assess trends in the balance components based on estimating catchment precipitation from the meteorological station data using different methods. Such a check (and, of course, others) would be necessary to define critical areas for the use of the gridded data, e.g., for the need to conduct rainfall-runoff modelling.

On the other hand, it has become clear that such data needs to be available for the engineering practice and that efforts to build and maintain such databases for Slovakia (and preferably the broader region) are urgently needed. Furthermore, the period covered should be extended and continued not only to the present but also further to the past. With regards to data management for practical water resources management, continuing the practice of adopting new reference periods for baselines and long-term characteristics derived from climatological and hydrological data can be recommended.

\section{Acknowledgements}

The research was supported by the Slovak Research and Development Agency under Contract Nos. APVV-18-0347 and APVV-20-0374, and the VEGA Agency Grant No. 1/0632/19. The support is gratefully acknowledged. We especially thank Professor Lapin of the Department of Meteorology and Climate Science at the Faculty of Mathematics, Physics and Informatics of Comenius University, Slovakia, for providing evapotranspiration data from Slovak climate stations. 


\section{REFERENCES}

Blaškovičová, L., et al. (2019) Determination of hydrological characteristics, sub-task: Hydrological Drought Assessment - Assessment of changes and trends of monthly and annual flow rates, unpublished report, Slovak Hydrometeorological Institute, 2019.

Damborská, I. - Gera, M. - Melo, M. - Lapin, M. - Nejedlík, P. (2015) Changes in the daily range of the air temperature in the mountainous part of Slovakia within the possible context of global warming. Meteorologische Zeitschrift, PrePub DOI $10.1127 /$ metz/2015/0569

Domokos, M. - Sass, J. (1990) Long-term water balances for subcatchments and partial national areas in the Danube basin. Journal of Hydrology 112, pp. 267-292. DOI: 10.1016/00221694(90)90019-T.

Duethmann, D. - Blöschl, G. (2018) Why has catchment evaporation increased in the past 40 years? A data-based study in Austria. Hydrol. Earth Syst. Sci. 22 (10), pp. 5143-5158. DOI: 10.5194/hess-22-5143-2018.

Ďurigová, M. - Hlavčová, K. - Komorníková, M. - Kalická, J. - Ballová, D. - Bacigál, T. (2019) Analysis of changes in average monthly flow rates in Slovakia in recent decades. Acta Hydrologica Slovaca. DOI: 10.31577/ahs-2019-0020.01.0002 Year 20, No. 1, 2019, 10-21.

Ďurigová, M. - Ballová, D. - Hlavčová, K. (2019) Analyses of Monthly Discharges in Slovakia Using Hydrological Exploratory Methods and Statistical Methods. Slovak Journal of Civil Engineering 27, pp. 36-43, https://doi.org/10.2478/sjce2019-0014.

Ďurigová, M. - Hlavčová, K. - Poórová, J. (2020) Detection of Changes in Hydrological Time Series during Recent Decades. Slovak Journal of Civil Engineering 28, 2020, pp. 56-62, https:/ / doi.org/10.2478/sjce-2020-0016.

Fendeková, M. - Poórová, J. - Slivová, V., et al. (2018) Hydrological drought in Slovakia and forecast of its development, Comenius University in Bratislava, Faculty of Natural Sciences.

Gao, H. - Tang, Q. - Ferguson, C. R. - Wood, E. F. - Lettenmaier, D. P. (2010) Estimating the water budget of major US river basins via remote sensing. International Journal of Remote Sensing 31 (14), pp. 3955-3978. DOI: 10.1080/01431161.2010.483488.

Garaj, M. - Pekárová, P. - Pekár, J. - Miklánek, P. (2019) The Changes of Water Balance in the Eastern Slovakia. World Multidisciplinary Earth Sciences Symposium (WMESS 2019), IOP Conf. Series: Earth and Environmental Science 362 (2019) 012014, doi:10.1088/1755-1315/362/1/012014.

Halmová, D. - Pekárová, P. - Bačová-Mitková, V. (2019) Longterm trend changes of monthly and extreme discharges for different time periods. Acta Hydrologica Slovaca Vol. 20, No. 2, 2019, pp. 122-130, doi: 10.31577/ahs-2019-0020.02.0014.

Hobbins, M. T. - Ramírez, J. A. - Brown, T. C. (2004) Trends in pan evaporation and actual evapotranspiration across the conterminous U.S.: Paradoxical or complementary? Geophys. Res. Lett. 31 (13), n/a-n/a. DOI: 10.1029/2004GL019846.
Hobbins, M. T. - Ramírez, J. A. - Brown, T. C. - Claessens, L. H. (2001) The complementary relationship in estimation of regional evapotranspiration: The complementary relationship areal evapotranspiration and advection-aridity models. Water Resour. Res. 37 (5), pp. 1367-1387. DOI: 10.1029/2000WR900358.

Holko, L. - Sleziak, P. - Danko, M. - Bičárová, S. - Pociask-Karteczka, J. (2020) Analysis of changes in hydrological cycle of a pristine mountain catchment. 1 . Water balance components and snow cover. Hydrol. Hydromech. 68, 2, 2020, pp. 180-191, doi: 10.2478/johh-2020-0010.

Huang, Y. - Franssen, H. J. - Herbst, M. - Hirschi, M. - Michel, D. - Seneviratne, S. I. et al. (2020) Evaluation of different methods for gap filling of long-term actual evapotranspiration time series measured by lysimeters. Vadose zone j. 19 (1). DOI: $10.1002 / v z j 2.20020$.

Jothityangkoon, Ch. - Sivapalan, M. (2009) Framework for exploration of climatic and landscape controls on catchment water balance, with emphasis on inter-annual variability. Journal of Hydrology 371 (1-4), pp. 154-168. DOI: 10.1016/j.jhydrol.2009.03.030.

Kramer, R. - Bounoua, L. - Zhang, P. - Wolfe, R. - Huntington, T. - Imhoff, M. et al. (2015) Evapotranspiration Trends Over the Eastern United States During the 20th Century. Hydrology 2 (2), pp. 93-111. DOI: 10.3390/hydrology2020093.

Keszeliová, A. (2020) Comparison of changes in territorial evaporation in selected river basins of Slovakia (Porovnanie zmien územného výparu vo vybraných povodiach Slovenska.) Meteorologický časopis / Meteorological Journal. Vol. 23, No. 2 (2020), pp. 103-112.

Lapin, M. - Damborská, I. - Gera, M. - Melo, M. - Hrvol, J. (2016) Potential and current evapotranspiration in Slovakia in the period 1951-2015 and scenarios of possible development until 2100, In: Proceedings of the International Conference in Kutná Hora, 28.-29.4.2016. Půdní a zemědělské sucho, Prague, VÚMOP, 210-225, ISBN 978-80-87361-55-9.

Lapin, M. - Melo, M. (2012) Modification of climate classifications for warmer climate conditions in Slovakia; Meteorological Magazine, 15, 2012, 67-7.

Makel, M. - Turbek J., et al. (2002) Hydrology - Terminological Interpretative Vocabulary, Bratislava, Ministry of the Environment of Slovakia, 157 p. ISSN 1335-1564

Mastrotheodoros, T. - Pappas, Ch. - Molnár, P. - Burlando, P. - Manoli, G. - Parajka, J. et al. (2020) More green and less blue water in the Alps during warmer summers. Nat. Clim. Chang. 10 (2), pp. 155-161. DOI: 10.1038/s41558-019-0676-5.

Melo, M. - Lapin, M. - Kapolková, H. - Pecho, J. - Kružicová, A. (2013) Climate Trends in the Slovak Part of the Carpathians. In: Kozak, J., Ostapowicz, K., Bytnerowicz, A., Wyžga, B. (eds.) (2013): The Carpathians: Integral Nature and Society Towards Sustainability, Springer-Verlag, Berlin, Heidelberg, pp. 131-150.

Mills, G. (2001) Ireland's water budget-model validation and a greenhouse experiment. Irish Geography 34 (2), pp. 124-134. DOI: 10.1080/00750770109555783. 
Milly, P. C. D. - Dunne, K. A. (2001) Trends in evaporation and surface cooling in the Mississippi River Basin. Geophys. Res. Lett. 28 (7), pp. 1219-1222. DOI: 10.1029/2000GL012321.

Parajka, J. - Szolgay, J. (1998) Grid-based mapping of long-term mean annual potential and actual evapotranspiration in Slovakia. Hydrology, water resources and ecology in headwaters. IAHS Publication 248. Headwater 98 conference, Apr. 20-23, 1998, Merano, Italy.

Parajka, J. - Szolgay J. - Mészároš, I. - Kostka, Z. (2004) Gridbased mapping of the long-term mean annual potential and actual evapotranspiration in upper Hron river basin, J. Hydrol. Hydromech., 52, 2004, 4, pp. 7 - 8.

Pramuk, B. - Pekárová, P. - Škoda, P. - Halmová, D. - Bačová Mitková, V. (2016) The identification of changes in the regime of daily discharges in Slovakia. Acta Hydrologica Slovaca, Vol. 17, No. 1, 2016, pp. 65 - 77.

Szalai, S. - Nejedlik, P. - Štastný, P. - Mikulová, K. - Szentimrey, T. - Bihari, Z. - Lakatos, M. (2012) Climate of the Carpathian Region, a project for a high resolution harmonised gridded database. Forum Carpaticum 2012, Stara Lesna.

Szentimrey, T. - Bihari, Z. (2007) Mathematical background of the spatial interpolation methods and the software Mish (Meteorological Interpolation based on Surface Homogenised Data Basis). Proceedings from the Conference on Spatial Interpolation in Climatology and Meteorology, Budapest, Hungary, 2004, COST Action 719, COST Office, pp. 17-27.

Szolgay, J. - Hlavčová, K. - Mosný, V. - Parajka, J. (1997) Temporal and spatial changes in the hydrological balance in Eastern Slovakia, STU, Bratislava, 213 p.

Tomas-Burguera, M. - Beguería, S. - Vicente-Serrano, S. M. (2021) Climatology and trends of reference evapotranspiration in Spain. Int J. Climatol 41 (S1). DOI: 10.1002/joc.6817.

Tomlain, J. (1997) Distribution of evapotranspiration in Slovakia for the period 1961-1990, Podzemna voda, III./1997 No. 1.

Trenberth, K. E. - Smith, L. - Qian, T. - Dai, A. - Fasullo, J. (2007) Estimates of the Global Water Budget and Its Annual Cycle Using Observational and Model Data. Journal of Hydrometeorology 8 (4), pp. 758-769. DOI: 10.1175/JHM600.1.

Ukkola, A. M. - Prentice, I. C. (2013) A worldwide analysis of trends in water-balance evapotranspiration. Hydrol. Earth Syst. Sci. 17 (10), pp. 4177-4187. DOI: 10.5194/hess-174177-2013.
Valent, P. - Výleta, R. (2015) Calculating areal rainfall using a more efficient IDW interpolation algorithm. Int. J. Eng. Res. Sci. 1, 2015, pp. 9-17.

Vido, J. - Nalevanková, P. (2020) Drought in the Upper Hron Region (Slovakia) between the Years 1984-2014. Water 12, 2020, 2887, doi:10.3390/w12102887.

Walter, M. T. - Wilks, D. S. - Parlange, J. - Schneider, R. L. (2004) Increasing Evapotranspiration from the Conterminous United States. J. Hydrometeor 5 (3), pp. 405-408. DOI: 10.1175/1525-7541(2004)005<0405:IEFTCU>2.0.CO;2.

Weingartner, R. - Viviroli, D. - Schädler, B. (2007) Water resources in mountain regions: a methodological approach to assess the water balance in a highland-lowland-system. Hydrol. Process. 21 (5), pp. 578-585. DOI: 10.1002/hyp.6268.

Xiao, M. - Gao, Ming - Vogel, Richard M. - Lettenmaier, Dennis P. (2020) Runoff and Evapotranspiration Elasticities in the Western United States: Are They Consistent With Dooge's Complementary Relationship? Water Resour. Res. 56 (8). DOI: 10.1029/2019WR026719.

Zhang, K. - Kimball, J. S. - Nemani, R. R. - Running, S. W. (2010) A continuous satellite-derived global record of land surface evapotranspiration from 1983 to 2006. Water Resour. Res. 46 (9). DOI: 10.1029/2009WR008800.

Zhang, K. - Kimball, J. S. - Nemani, R. R. - Running, S. W. Hong, Y. - Gourley, Jonathan J. - Yu, Z. (2015) Vegetation Greening and Climate Change Promote Multidecadal Rises of Global Land Evapotranspiration. Scientific reports 5, p. 15956. DOI: $10.1038 /$ srep15956.

Zhang, L. - Dawes, W. R. - Walker, G. R. (2001) Response of mean annual evapotranspiration to vegetation changes at catchment scale. Water Resour. Res. 37 (3), pp. 701-708. DOI: 10.1029/2000WR900325.

Zhang, Y. - Leuning, R. - Chiew, Francis H. S. - Wang, E. - Zhang, L. - Liu, Ch., et al. (2012) Decadal Trends in Evaporation from Global Energy and Water Balances. Journal of Hydrometeorology 13 (1), pp. 379-391. DOI: 10.1175/ JHM-D-11-012.1. 